\title{
Cultural and aesthetic development of elementary school students in environmental education as a current pedagogical problem
КУЛЬТУРНО-ЭСТЕТИЧЕСКОЕ РАЗВИТИЕ МЛАДШИХ ШКОЛЬНИКОВ В ПРОБЛЕМА ЭКОЛОГИЧЕСКОМ ОБРАЗОВАНИИ КАК АКТУАЛЬНАЯ ПЕДАГОГИЧЕСКАЯ
}

Received: March 15, 2021

\author{
Accepted: April 28, 2021
}

Written by:

Irina Aryabkina ${ }^{52}$

https://orcid.org/0000-0002-8765-2153

Tatiana Kudashova ${ }^{53}$

https://orcid.org/0000-0002-0645-8704

Alexander Bulynin ${ }^{54}$

https://orcid.org/0000-0001-6107-2997

Fatima Aliphanova ${ }^{55}$

https://orcid.org/0000-0002-1944-4512

Elena Silantyeva ${ }^{56}$

https://orcid.org/0000-0003-3589-0579

\begin{abstract}
The purpose of the article is to analyze such a problem of pedagogical science at the present stage as the cultural and aesthetic development of primary school children in environmental education. The article reveals the essential and content characteristics of the concepts "cultural development", "aesthetic culture"," environmental education"," ecological culture","cultural and aesthetic development of primary school children in environmental education". The cultural and aesthetic development of primary school children in environmental education is considered as a way of forming a harmonious, integral, truly intelligent, civilized and spiritual personality. The article presents the materials, methods, pedagogical conditions, the results of an experiment to determine the level of cultural and aesthetic development of primary school children in environmental education through familiarity with the natural world, as well as the tasks facing the modern primary school to form the cultural and aesthetic development of primary school children in environmental education.
\end{abstract}

\begin{abstract}
Аннотация
Целью статьи является анализ такой проблемы педагогической науки на современном этапе, как культурно-эстетическое развитие младших школьников в экологическом образовании. Раскрываются сущностно-содержательные характеристики понятий «культурное развитие», «эстетическая культура», «экологическое образование», «экологическая культура», «культурно-эстетическое развитие младших школьников в экологическом образовании». Культурно-эстетическое развитие младших школьников в экологическом образовании рассматривается как способ формирования гармоничной, целостной, подлинно интеллигентной, цивилизованной и духовной личности. В статье представлены материалы, методы, педагогические условия, результаты эксперимента по определению уровня культурно-эстетического развития младших школьников в экологическом образовании через знакомство с миром природы, а также задачи, стоящие перед современной начальной школой по культурно-эстетическому развитию младших школьников в экологическом образовании.
\end{abstract}

\footnotetext{
52 Doctor of pedagogical sciences, professor of the Ulyanovsk State University of Education, Russian Federation.

53 Psychologist, Zaokskaya school for high-demand students, Russian Federation.

${ }^{54}$ Doctor of pedagogical sciences, professor of the Ulyanovsk State University, Russian Federation.

55 Doctor of pedagogical sciences, professor of the Chechen State University, Russian Federation.

${ }^{56} \mathrm{PhD}$ in Art, Associate professor of the Ulyanovsk State University, Russian Federation.
} 
Palabras clave: cultural and aesthetic development, elementary school students, environmental education.

\section{Introduction}

The XXI century is characterized by a high level of scientific and technological progress. The interaction of man and nature, society and its environment in the context of the rapid growth of industry has reached critical proportions. There is a threat to the very existence of humanity, as there is a continuous depletion of natural resources and dangerous pollution of the environment for the life of living beings. The most serious economic, political, and social problems turned out to be related to the problems of climate evolution, the problems of biosphere stability, the study of raw materials, and so on.

Scientist N. N. Nikitina asserts that our postindustrial society, the main reference point of which is the maximum consumption of material goods and the use of the surrounding world for their greatest satisfaction, gave rise to the "cybernetic man" (Nikitina, 2008). E. Fromm touches upon a "cybernetic person" is, on the one hand, a highly intelligent, technically educated person, but on the other hand, not capable of truly human relations and spiritually alienated from the surrounding world (Fromm, 1990). Since it is not typical for a "cybernetic person" to feel responsible for the state of the environment, the consequences of this phenomenon can be seen both in the system of social relations and in the environmental crisis.

Researcher N. V. Blagoveshchenskaya's opinion of " the "conquest of nature" led to environmental illiteracy and technocracy." The scientist believes that this is why the society has an acute problem of forming ecological thinking, without which it is impossible to revive the greatness of our country (Blagoveshchenskaya, 2008).

At the end of the XX century, the change of value orientations led to changes in both cross-cultural and social relations. The desire of the world community to move to sustainable development, in connection with the current environmental situation, allows us to look at the greening of education in a new way.

According to $\mathrm{Yu}$. A. Sharonova, the emergence of environmental problems is primarily due to socio-environmental factors. These problems should be solved not only by technical means, but also by reorienting people's values, attitudes and
Ключевые слова: культурно-эстетическое развитие, младшие школьники, экологическое образование.

behavior towards the environment. Humanity is aware of the need to form a new mentality associated with the views on the environmentally safe and sustainable development of society. Public environmental awareness should ensure the normal functioning of all mechanisms of social control. Society should consciously give priority to the issues of maintaining a favorable state of the environment, as well as to the issues of environmental education of the younger generation (Sharonova, 2005).

In recent decades, our society has come to understand that it is necessary to make changes in the state policy in the field of education, rethinking the philosophy and concept of Russian education at all levels. According to such documents of international and national significance as the "National Strategy for Environmental Education in the Russian Federation", "Fundamentals of the state policy in the field of environmental development of Russia for the period up to 2030" (Decree No. N 176, 2017) and others, environmental education has been identified as a priority area of general education. In this regard, there is an urgency of the problems of environmental education, the main goal of which is the formation of the ecological worldview of the individual. This is largely facilitated by the integration of environmental and aesthetic aspects of human development in a value context, which is embodied in environmental and aesthetic education.

Due to the fact that today the priority direction of modern education is the mental development of students, the cultural and aesthetic development of the younger generation is given very little attention. This leads to problems of interpersonal interaction, loss of spiritual orientation, and dynamics of antisocial behavior of the younger generation. At the same time, it is obvious that aesthetic education, due to the huge emotional impact on the spiritual world of a growing person, has a huge impact on his sensory sphere, allows him to see the surrounding reality "from a different angle", fully feeling its eternal value. Therefore, the issue of cultural and aesthetic development of a person who has a biosphere worldview, a protective attitude to the environment, is an urgent problem today. The 


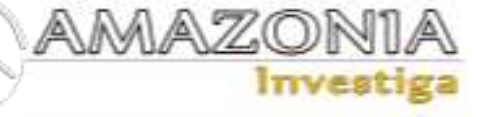

analysis of the scientific literature has shown that this problem is not sufficiently developed in modern pedagogical science.

The actualization of the problem of studying the cultural and aesthetic development of elementary school students in environmental education is an urgent problem of modern education.

\section{Theoretical framework}

To develop a meaningful characteristic of the concept of "cultural and aesthetic development of an elementary school students in environmental education ", it is necessary to consider the definitions of "cultural development", "aesthetic culture", "environmental education " and "environmental culture".

\section{Cultural development}

Various scientific studies by Russian scientists on the development of personality "revealed a common trend emerging gap between education and culture, which resulted in the collapse of a true culture, and its gradual isolation from the school, reducing the classical artistic heritage in school curricula, in secrecy and elitism of the processes of initiation to art, traditional old contents and methods of aesthetic education and enlightenment of the people" (Shkolyar, 2007). According to the "Fundamentals of the State Cultural Policy" (Decree No. 808, 2014), the culture was elevated to the rank of national priorities and is recognized as one of the major growth factors of the quality of life and harmonization of public relations, the guarantor of a common cultural space and territorial integrity of our country. The main goals of modern state policy are the formation of a harmoniously developed personality and the strengthening of the unity of Russian society through priority cultural development (Decree No. 808, 2014).

At a joint meeting of the State Council and the Presidential Council for Culture and the Arts, dedicated to the implementation of the state cultural policy, Russian President Vladimir Putin emphasized the particular importance of developing a strategy for state cultural policy. $\mathrm{He}$ also stressed the importance of high-quality legislative support for the tasks of the policy in the field of culture.

In accordance with the National Doctrine of Education in the Russian Federation, the strategy of modernization, the processes of humanization and humanitarization, strengthening the general cultural content of education, focused on the acceptance and awareness of cultural experience, are currently becoming relevant (Slobodchikov, 2018).

There are many definitions of the concept of "culture". The pedagogical encyclopedic dictionary gives the following definition: "culture (from the Latin cultura - cultivation, upbringing, education, development, veneration), a historically defined level of development of society, creative forces and human abilities, expressed in the types and forms of organization of people's lives and activities, in their relationships, as well as in the material and spiritual values created by them..." (Bim-Bad, 2002).

I. V. Aryabkina, "the interaction of man and culture exists and manifests itself as a dialectical unity of the source and result of their existence, in which both phenomena are mutually generating each other and do not exist without each other" (Aryabkina, 2010).

The external criterion for the cultural development of a society is culture in its broadest sense. The level of scientific, moral, artistic and aesthetic development is an indicator of the cultural development of both society and the individual.

According to A. Ya. Flier, "cultural development" is what allows a person to understand and use the knowledge that has entered into everyday life, which constitute in this society the norm of "general social erudition" (laws, customs, prohibitions, rules of etiquette, etc.), ideological foundations, generally accepted symbols, value orientations, etc. (Flier, 2004). With the ability to take responsibility; the ability to resolve conflict situations, avoiding violence; competencies related to life in a multicultural society, which includes respect for the traditions and beliefs of different peoples (Oleshkov \& Uvarov, 2006).

\section{Aesthetic culture}

The analysis of philosophical and historical works shows that the idea of forming an aesthetic culture of the individual has its roots in the depths of centuries, although the very concept of "aesthetic" originates only in the XVIII century.

It is known that the core of culture is art. Through art, the cultural situation is captured. Works of art reflect the facts of the previous culture in new senses, while maintaining their semantic core 
(Spiridonova, 2018). Researcher I. V. Aryabkina poits out the communication of a person with art, his independent creative activity in the formation of his cultural level is of great importance for the cultural development of the individual. The aesthetic content of centuries-old classical elite works of art has such an educational value, the impact of which only increases over the years. Art is capable of solving the problems of the human spirit (Aryabkina, 2010). The cultural and aesthetic demands of a society are an indicator of the ability of a given society to transform. Culture does not stand still, it is always in development. Therefore, there is a constant birth of new aesthetic objects that determine the development of cultural and aesthetic values, and they, in turn, are concretized in the goals of activity, life attitudes of a person.

The aesthetic culture of the individual has a deep essential certainty associated with the processes of aesthetic development of the individual. According to the V. A. Rasumniy, the essence of the aesthetic development of the individual is the purposeful and active formation and improvement of the system of aesthetic needs of the individual, the sphere of his spiritual life, which is generally called "aesthetic culture" (Rasumniy, 2000). Through aesthetic culture, a social position based on humanistic values is formed, and the emotional and communicative spheres of the younger generation are harmonized.

\section{Ecological education and "environmental culture $^{\prime \prime}$}

For many centuries, the society was dominated by anthropocentrism, i.e., the utilitarianconsumer attitude to nature prevailed, which was perceived as a storeroom from which you can take, without giving anything in return. Therefore, it is necessary to change the paradigms of public consciousness and valuable guidelines. Thus, initially it is necessary to abandon the opposition of the surrounding world and culture. Both nature and culture are in constant interaction with each other, playing a huge role in human life. Culture influences the changes that occur in nature, but it cannot exist without it, borrowing from it both resources and individual forms and patterns. Man himself has a dual nature: biological and social.

The ecological crisis has demonstrated the acute lack of ecological culture in modern society and the importance of serious transformations, such as new moral attitudes, the reassessment of values, the formation of ecological consciousness of the individual (a reasonable attitude to nature and to oneself).

At present, it has become obvious for pedagogical science that environmental education should become an obligatory element of modern education at all levels.

Environmental education is the process of training, education and development of a person in the field of his relationship with the environment. The goal of environmental education is most often called the formation of ecological culture (Mironov, 2019).

What does the definition of "ecological culture" include? I. N. Ponomareva declared that "ecological culture" is a measure, a way of implementing and developing natural-like relations of a person in the process of spiritual and material-activity development of the values of nature (Ponomareva, 1998). I. D. Zverev believes that ecological culture presupposes the presence of certain knowledge and beliefs, readiness for activity, as well as his practical actions, consistent with the requirement to take care of nature (Zverev, 2007). Russin scientist in the field of art pedagogy L. P. Pechko considers that ecological culture include: culture of cognitive activity of students in the development of the experience of humankind in relation to nature; culture of work emerging in the process of employment environmental activities; culture of spiritual communion with nature (Pechko, 2008).

Thus, under environmental culture we understand the high level of environmental knowledge and activities as a result of formation of ecological consciousness and human behavior, and purposeful interaction with nature.

The ideas of sustainable development involve the integration of their goals into educational programs for the formation of an ecological culture both for each individual and for society as a whole.

Undoubtedly, the formation of ecological culture contributes to the spiritual and moral education of the individual, the education of the younger generation of rationalism, moderation, integrity of world perception, self-control, the ability to see expressiveness in every natural object and phenomenon. It is also important that, in the process of taking care of nature, the attitude of a person to himself as one of the objects of the surrounding world also changes. Researcher Yu. S. Efimova reveals the formation of ecological 


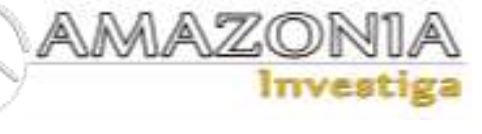

culture also contributes to the social evolution of our society and the development of innovative technologies (Efimova, 2016).

The problem of forming an ecological culture among the younger generation is the most important task of modern education, which must be solved methodologically and practically.

In our time, the Russian educational system has begun to pay more and more attention to the environmental education of the younger generation. According to the Federal State Educational Standards of Elementary General Education adopted in the Russian Federation, at the stage of general education, the spiritual and moral development of students is carried out, aimed both at introducing younger students to the basic national values of Russian society, universal values, and at forming and expanding the experience of positive interaction with the surrounding world, educating the basics of ecological culture (Federal State Educational Standards of Elementary General Education, 2011).

The mission of the current stage of the development of the educational system should be the restructuring of the consciousness and behavior of the individual to the ecological lifestyle as positively correlating with the socioeconomic system of the society of sustainable development, in other words, the formation of the ecological culture of the individual and society as a whole.

\section{Cultural and aesthetic development of an elementary school students in environmental education}

Today, there is an opinion in scientific circles that the twenty-first century should become an era of true humanization of culture, which is impossible without its greening. Here a particularly important role is played by the cultural and aesthetic development of the individual in the ecological aspect, which, according to L. P. Pechko, requires "the development of the ability to understand and evaluate the natural world as the cradle of man, as an environment that is the origin and continuation of human society, as a world of life comparable in value to human life" (Pechko, 2008).

The humanization and humanitarization of education, which have an impact not only on improving the level of education of children, but also contribute to strengthening their health, depends on whether aesthetic ways of cognizing the surrounding reality take place in education, as A. F. Yafalyan thinks. The scientist writes that the aesthetic component in educational activities contributes to the formation of a holistic attitude to the world, the creation of an aesthetic image of the world, harmonizes the inner world of each child" (Yafalyan, 2007).

Based on the above, we can conclude that the content characteristic of the concept of "cultural and aesthetic development of an elementary school student in environmental education" is the process and result of quantitative and qualitative changes in the personality, characterized by the formation of ecological and aesthetic knowledge, emotional and value attitude to aesthetic objects and phenomena of the surrounding reality as aesthetic and spiritual values, models of cultural and aesthetic interaction with the surrounding world.

Numerous studies prove that it is the elementary school age that is most susceptible to cultural and aesthetic development in environmental education. At this age stage, there is not only an active process of forming knowledge, experiences, assessments, but also the development of individual abilities and interests, including responsiveness and receptivity. The world of nature with its brightness and diversity affects the emotional and sensory sphere of younger schoolchildren and causes them an emotional response, an active interest in the world around them, a desire to bring them closer to themselves, to consider, to understand, to express their impressions and emotions through creative activity. It is proved that children at this age are characterized by a unique unity of knowledge and experiences, which allows the teacher to form the foundations of a responsible attitude to the world around them by aesthetic means. The knowledge about the world around us, acquired by children of elementary school age through works of art, creative activity, can later be transformed into strong beliefs.

We agree with L. P. Pechko that in elementary school it is necessary: "to develop a versatile aesthetic vision of nature and its understanding; to support associative mutual transfers of elements of artistic and aesthetic images of nature; to awaken and support a vivid sense of experiencing the beautiful and at the same time to understand the value of the original, expressive and "ordinary", to reflect the assessments, statements of scientists, writers, poets, artists about the aesthetic properties of nature; to activate the taste sensory-harmonic 
sense of the child; comparison of objectively reasoned and subjective assessment of natural phenomena; organization of creative (imaginary and real) actions with natural objects and materials by the teacher" (Pechko, 2008).

So, the cultural and aesthetic development of elementary school students is aimed at their ecodevelopment in cultural, aesthetic, spiritual, moral and intellectual terms. But this is possible when creating pedagogical conditions that can act as a characteristic of an integrated system that allows you to synthesize the possibilities of environmental and aesthetic education of younger students, implementing their principles and resources

\section{Methodology}

The formation of cultural and aesthetic development of elementary school students in environmental education is based on the following principles:

- integration (combines personal-oriented and reflexive-active aspects in pedagogical approaches, and natural-scientific and culturalaesthetic components of the studied objects and phenomena in the content of the educational material);

- versatile interaction (including students in a variety of artistic and creative activities related to the surrounding world);

- integrity (the artistic image of an ecological object created at each lesson is always included in the holistic picture of the world);

- scientific (the artistic image created by the teacher should be based on the scientific picture of the world) (Benevolskaya, 2010).

Our research was based on the methods of theoretical analysis of the provisions of philosophical, historical, pedagogical, sociological, cultural science, as well as a set of well-founded and reliable information methods in research practice: retrospecific analysis of domestic and foreign experience of cultural and aesthetic development of the individual; theoretical methods (comparison, analogy, analysis, synthesis, abstraction, concretization, classification); traditional pedagogical methods (observation, questioning, testing), empirical methods, pedagogical formative experiment); methods of studying and generalizing modern pedagogical experience; methods of statistical data processing; methods of diagnostics and research of educational products, including diagnostic methods (a modified version of
"Diagnostics of the formation of environmental knowledge" by T. A. Serebryakova (Serebryakova, 2011), "Verbal associative method of AESOP" by S. D. Deryabo and V. A. Yasvin (Deryabo, \& Yasvin 1995), methods L. P. Pechko "Aesthetic portrait of nature" (Pechko, 2008) and the methodology for diagnosing the motivation of interaction with nature "Alternative" S. D. Deryabo and V. A. Yasvin (Deryabo, Yasvin 1995).

The experimental study was conducted in two stages (the 1st stage - the ascertaining, the 2nd stage - the control). At the first (ascertaining) stage, we conducted a primary diagnosis of the level of cultural and aesthetic development of students in the first classes. Also at this stage, the pedagogical conditions stated in the hypothesis for improving the effectiveness of cultural and aesthetic development of younger schoolchildren in the conditions of extracurricular activities of environmental content were tested, which will be indicated below.

At the second (control) stage of the experiment, we performed a multidimensional statistical procedure that collects data containing information about two samples, and then arranges the objects into a homogeneous group according to three criteria. Based on the cluster analysis, the criteria were combined into an integrative criterion. At this stage, we conducted a final diagnosis of the level of formation of the integrated criterion in the experimental group and the control group at the end of the experiment.

\section{Results and discussion}

As a result of a retrospective analysis of the literature on the problem under study, we identified the following pedagogical conditions for the formation of cultural and aesthetic development of elementary school students in environmental education:

- creating a friendly atmosphere in elementary school lessons that promotes the perception of environmental and aesthetic information provided by the teacher;

- the study of environmental objects that contribute to the emotional involvement of students in the work process and the development of a non-consumer attitude to the natural world; - the creation of artistic images of environmental objects;

- the diversity of the studied ecological objects (the largest number of natural and cultural phenomena); 


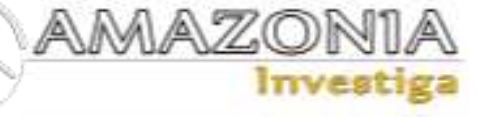

- taking into account the age characteristics of children of elementary school age in the context of the perception of environmental objects.

This experimental work was carried out on the basis of three schools in the Tula region (Russian Federation). In total, 210 elementary school students took part in the experimental work. Of these, 103 elementary school students made up the experimental group, 107 elementary school students - the control group. The studies conducted at the ascertaining stage of the experiment showed that the majority of elementary school students in the experimental and control groups have a low level of cultural and aesthetic development - 51 elementary school students $(49.5 \%)$ in the experimental group and 52 people $(48.6 \%)$ in the control group; the average level - 36 elementary school students $(35 \%)$ in the experimental group and 39 people $(36.4 \%)$ in the control group; a high level of cultural and aesthetic development is diagnosed in 16 elementary school students $(15.5 \%)$ in the experimental group and also 16 elementary school students $(15 \%)$ in the control group.

At this stage of the experimental work, we tested the pedagogical conditions for improving the effectiveness of the cultural and aesthetic development of elementary school students in the conditions of extracurricular activities of ecological content. The first pedagogical condition is the actualization of the aesthetic potential of extracurricular activities of ecological content. This pedagogical condition implies the creation of a special cultural and aesthetic educational environment. This includes introducing cultural and aesthetic elements into such a component of the educational process of elementary school as extracurricular activities, and helping each elementary school students to realize his creative potential, giving him the opportunity to feel the need to strive to achieve beauty and harmony. When implementing the above condition, we were based on the fact that in the context of education, the peculiarity of art is the concentration of creative experience, and this is the wealth of human civilization. The aesthetic attitude of those who create to the world around them is reflected in the works of art. Realizing this pedagogical condition, we tried to form an understanding of the unity of all the diversity of the surrounding reality among primary school students.

The implementation of this pedagogical condition was carried out by us in various directions: the organization of cultural and aesthetic extracurricular activities of ecological content; visits to cultural institutions; aestheticization of the educational environment; active participation in cultural and aesthetic events at the school, district, regional and AllRussian levels. We tried to fill the content of the events with information that helps children to understand the relationship, mutual enrichment of various types of art, through the works of which the richness, diversity, expressiveness of objects and natural phenomena is reflected.

The key direction in our work was the organization of cultural and aesthetic extracurricular activities of ecological content. To make classes on cultural and aesthetic development of elementary school students in the conditions of extracurricular activities of ecological content more interesting, diverse, and to increase their effectiveness, along with traditional ones, we used innovative forms, methods, and means of teaching and upbringing. For the purpose of cultural and aesthetic development of elementary school students, we tried to connect the knowledge gained by children in the classroom with the creative aesthetically oriented work of students. An important role in the implementation of this pedagogical condition is played by the aestheticization of the educational environment. With this approach to the problem of cultural and aesthetic development of elementary school students, students form a special view of the world around them and what is happening in it, open up the opportunity to better understand themselves, empathize with others, discover and develop their creative abilities, as well as improve their level of culture.

The second pedagogical condition necessary for the successful cultural and aesthetic development of elementary school students in the conditions of extracurricular activities of ecological content is the use of the unity of cultural, axiological, polychartistic, expressive (expressive), systemactivity with the system-forming role of the integrated approach. In the course of experimental work, we found that the combination of the key methodological foundations of all the above approaches allows younger students to master and apply in practice the mechanisms of cultural and aesthetic development.

The third pedagogical condition is the introduction into the educational process of elementary school students of the program of extracurricular activities of ecological content "Art inspired by nature" for elementary school 
students. The aim of the program was to develop elementary school students understanding of the cultural diversity of the surrounding world, the formation of environmentally consistent behavior. During the implementation of this program, it was necessary to solve the following tasks: on the basis of studying works of art, to acquaint elementary school students with the expressiveness of nature objects; to develop elementary school students expressive and aesthetic abilities in mastering nature and enriching their ecological and aesthetic consciousness and culture; to form the ability of elementary school students to evaluate their behavior and the behavior of other people in relation to the surrounding world from the position of following spiritual and moral values; to involve elementary school students in ecological and aesthetic activities as a way of applying the unity of cultural, axiological, polychartistic, expressive (expressive), systemactivity with the system-forming role of an integrated approach to cultural and aesthetic development.

When organizing extracurricular activities of ecological and aesthetic content, we took into account the fact that the cultural and aesthetic development of elementary school students is influenced by external factors: the attitude of the educational institution to the cultural and aesthetic development of elementary school students; complex pedagogical interaction; cultural and aesthetic competence of the teacher.

We found out that the pedagogical conditions developed and implemented by us in the course of the study affect the formation of the cultural and aesthetic development of elementary school students in environmental education according to the following criteria: cognitive-evaluative, emotional-value, and motivational-behavioral.

To identify the level of development of the cognitive assessment criterion, a modified version of the "Diagnosis of the formation of environmental knowledge" by T. A. Serebryakova (Serebryakova, 2011) was used. Ranking the final results according to their levels of formation, we obtained the following dynamics: the high level of development of the cognitive evaluation criterion was $33 \%$ (delta $+12.6 \%$ ), the average $52.4 \%$ (delta +24.2 ), the low level $30 \%$ (delta - 14.9).

To identify the level of development of the emotional-value criterion, the "Verbal associative method of AESOP" was used by S. D. Deryabo and V. A. Yasvin (Deryabo, Yasvin
1995) and the methodology L. P. Pechko "The Aesthetic portrait of nature" (Pechko, 2008). Positive dynamics were observed at all levels. The number of respondents with a high level of development of the emotional-value criterion was $22 \%$ (delta $+21.3 \%$ ), with an average level of development of $67 \%$ (delta $+35 \%$ ), a low level of $59.9 \%$ (delta $-16.7 \%)$.

To identify the level of development of the motivational-behavioral criterion, we tested the methodology for diagnosing the motivation of interaction with nature "Alternative" S. D. Deryabo and V. A. Yasvin (Deryabo, \& Yasvin 1995). The ranking of the final results of the experiment also showed positive results: a high level of development of the motivationalbehavioral criterion is observed in $37.9 \%$ (delta $+11.7 \%$ ) of elemtntary school students, an average level in $58.2 \%$ (delta $+12.6 \%$ ), a low level of $3.9 \%$ (delta $-24.3 \%$ ).

The reliability of the work efficiency in the framework of our study is confirmed by the correlation of samples by a qualitatively determined feature. Due to the fact that the study concerns the comparison of two samples by the frequency of occurrence of the effect of interest to us, we used the criterion of the angular transformation of R. Fischer- $\varphi^{*}$.

The calculation results showed that $\varphi^{*}=6.652$. The specified empirical value $\varphi^{*}$ is in the zone of significance.

\section{Conclusion}

Thus, the analysis of the results obtained in the course of the study showed a positive trend in the formation all components of the cultural and aesthetic development of elementary school students in environmental education. It can be concluded that the formation of cultural and aesthetic development of elementary school students in environmental education contributes to the formation of a harmonious, holistic, truly intelligent, civilized and spiritual personality.

The philosophical and historical analysis of the problem under study shows that in order to achieve the effectiveness of the process of the formation cultural and aesthetic development of elementary school students in environmental education, the modern school faces the following tasks:

1) the development in elementary school students of aesthetic taste, the ability to artistic and creative activities related to the surrounding world; 


\section{AMAZONDA}

2) formation of ecological and aesthetic feelings, spiritual and moral qualities in elementary school students through sensory comprehension of the natural world;

3) involvement of elementary school students in artistic and creative activities of ecological content;

4) developing the need for elementary school students to acquire knowledge related to cultural and aesthetic development of elementary school students in environmental education.

It is also important to note that a teacher who is engaged in the formation of cultural and aesthetic development of younger schoolchildren in the conditions of extracurricular activities of environmental content must have not only environmental, but also art history knowledge and skills.

\section{References}

Aryabkina, I.V. (2010). Formation of cultural and aesthetic competence of elementary school teachers on the basis of a personality-oriented approach: theoretical aspects: monograph. Moscow: Flinta: The science.

Benevolskaya, N.A. (2010). Artistic activity as a means of ecological education of younger schoolchildren and adolescents (abstract of the dissertation of the Candidate of Pedagogical Sciences). Moscow City Pedagogical University, Moscow.

Bim-Bad, B.M, (2002). Pedagogical encyclopedic dictionary. Moscow: Great Russian Encyclopedia.

Blagoveshchenskaya, N.V. (2008). Ecological education and spiritual and moral education as a condition for sustainable development of the Ulyanovsk region. Ulyanovsk Spiritual and moral education and ecological education: methodological recommendations, p. $23-28$. Ulyanovsk: UIPK PRO.

Decree No. 808. Fundamentals of the State cultural policy, December 24, 2014. URL: https://base.garant.ru/70828330/\#friends

Decree No. 176. Fundamentals of the state policy in the field of environmental development of Russia for the period up to 2030, April 19, 2017 Deryabo, S.D., \& Yasvin, V.A. (1995). Methods of diagnostics and correction of attitude to nature. Moscow: TSKFL RAO.

Efimova, Yu. S. (2016). Philosophical aspects of environmental protection. Young scientist. 10, p. 410 - 412. Kazan: Young scientist.

Federal State Educational Standard of Elementary General Education: text with amendments and additions for 2011. (2011). Standards of the Second Generation. Moscow: Prosveshchenie.

Flier, A.Ya. (2004). "Culture of the world" and cultural competence. Observatory of Culture, 2, p. $4-11$.

Fromm, E. (1990). The spiritual essence of man. The ability to do good and evil. Moskow: Philos. Nauki, 8, p.88 - 95.

Mironov, A.V. (2019). Theory and technology of teaching the integrated course " The world around us". Moscow: Urait.

Nikitina, N.N. (2008). Spiritual and moral education: the essence and problems. Pedagogic of culture, 7. URL: https://pedagogikacultura.ru/7-2008-g/333-nikitina-7

Oleshkov, M.Yu, \& Uvarov, V.M. (2006). Modern educational process: basic concepts and terms. Moscow: Sputnik + Company

Pechko, L.P. (2008). Expressiveness of the aesthetics of nature and the culture of personality. Ulyanovsk: UISTU.

Ponomareva, I.N. (1998). Regional aspects of environmental education in the schools of Russia. Moscow: Tobolsk, A Rational system of environmental education, p.15-17.

Rasumniy, V.A. (2000). The Drama of existence or discovery of meaning. Philosophical and pedagogical essays. Moscow: Pihta.

Serebryakova, T.A. (2011). Ecological education in preschool age. Moscow: Akademiya.

Sharonova, Yu. A. (2005). Ecological education of rural schoolchildren in the system of additional education of children. Ulyanovsk: UGSHA.

Shkolyar, L.V. (2007). Art education in Russia: problems and prospects. Pedagogy of art as a new direction of humanitarian knowledge: materials of the International scientific session, May 29-31, p. 9-15. Moscow: IHO RAO.

Slobodchikov, V.I. (2018). National Doctrine of Education of the Russian Federation: project. Moscow: B.I.

Spiridonova, A.A. (2018). Formation of cultural relationship younger students to the reality in extracurricular activities on the basis of multi-art approach (dis...kand. ped. Sciences). Ulyanovsk state university, Ulyanovsk.

Yafalyan, A.F. (2007). Creating an aesthetic space in the conditions of educational institutions. Holistic educational environment from kindergarten to University, 5, p. $12-18$. Ekaterinburg.

Zverev, I.D. (2007). Ecology in school education: A new aspect of education. Moscow: Eco. 